\title{
ELINIKÄINEN OPPIMINEN SUOMESSA JA MUUALLA
}

\author{
Kari Nyyssölä \& Kimmo Hämäläinen
}

Opetushallitus on tehnyt Euroopan ammatillisen

koulutuksen kehittämiskeskukselle CEDEFOP:Ile

maaraportin, jossa kartoitetaan elinikäisen oppimisen

toteutumista Suomessa. Raportin perusteella elinikäisen oppimisen periaatteet otetaan huomioon varsin hyvin

koulutusjärjestelmässä. Suomi pärjää hyvin kansain-

välisessä vertailussa. Työtä on kuitenkin vielä tehtävä,

jotta kaikki elinikäisen oppimisen tavoitteet

saavutettaisiin.

$\mathrm{E}^{\prime}$ linikäisen oppimisen ympärille on syntynyt äsiteviidakko, jonka konkretisoituminen on osoittautunut sitä vaikeammaksi, mitä tiiviimmin se yhdistetään koulutuspoliittiseen suunnitteluun ja keskusteluun. Elinikäisen oppimisen perusajatus on kuitenkin selkeä: ihminen kykenee oppimaan koko ikänsä ja selviytyäkseen hänen on opittava koko ikänsä.

Elinikäinen oppiminen nousi vakavassa mielessä yhteiskuntapoliittiseen keskusteluun 1960luvulla. Tuolloin aikuiskoulutukselle alettiin hakea uudenlaista roolia yhteiskunnallisten ongelmien ratkaisuissa. Keskustelun käynnistäjänä oli UNESCO, johon sittemmin yhtyivät myös OECD ja Euroopan unioni. Viime aikoina keskeiseksi elinikäistä oppimista luotsaavaksi asiakirjaksi on noussut Euroopan unionin laatima Memorandum on Lifelong learning (EU 2000). Muistiossa nostetaan esille kuusi perustavoitetta (key message) elinikäiselle oppimiselle:

1 Uudet perustaidot kaikille, joiksi on määritelty IT-taidot, kielitaito, tekninen sivistys, yrittäjyystaidot sekä sosiaaliset taidot. Lisäksi ko- rostetaan oppimiseen oppimisen taitoa.

2 Inhimillisiin voimavaroihin panostaminen, koulutuksen rahoittamisessa. Työpaikalla tapahtuvassa oppimisessa tulee ottaa huomioon erityisesti vanhemmat työntekijät, joista on tulossa yhä tärkeämpi voimavara yhteiskunnalle.

3 Opettamisen ja oppimisen innovaatiot, missä 3 painotetaan IT-pohjaisten oppimisympäristöjen merkitystä. Myös opettajan muuttuvaa roolia halutaan tukea. Opettajista on yhä enemmän tulossa oppimisen oppaita, mentoreita ja välittäjiä. Tavoitteena on, että opiskelijat ottaisivat itse vastuuta omasta opiskelustaan ja oppimisestaan.

$\Lambda$ Oppimisen arvottaminen, jossa tavoitellaan 4 erityisesti non-formaalin ja informaalin oppimisen parempaa tunnustamista ja arvioimista.

5 Ohjauksen ja neuvonnan kehittäminen, jossa $\mathcal{~ t a v o i t t e e n a ~ o n , ~ e t t a ̈ ~ k a i k k i ~ E u r o o p a s s a ~ v o i - ~}$ sivat kaikenikäisinä saada korkealaatuista informaatiota ja opastusta oppimismahdollisuuksista. Samalla korostetaan koulutustarjonnan muuttamista enemmän tarjontaan perustuvasta kysyn- 
tään perustuvaksi. Myös oppimisvaikeuksiin ja koulutuksesta syrjään jääneisiin (drop outs) on kiinnitettävä erityistä huomioita. 6 Koulutuksen tuominen lähemmäs kotia, jolsuutta sekä parempaa saatavuutta esimerkiksi informaatio- ja viestintätekniikkaa hyödyntämällä.

Suomessa elinikäistä oppimista lanseerattiin pariinkin otteeseen 1970- ja 1980-luvuilla, mutta vasta 1990-luvun puolivälistä lähtien termi ilmaantui toden teolla suomalaiseen koulutuspoliittiseen keskusteluun. Taustalla vaikutti paljolti tietotekniikan kehittyminen ja tietoyhteiskunnasta käydyn keskustelun viriäminen: elinikäisen oppimisen katsottiin soveltuvan hyvin tietoyhteiskunnan kansalaisille työn ja elämän kehittämisvälineeksi.

2000-luvulle tultaessa elinikäinen oppiminen on läpäissyt suomalaisen koulutusjärjestelmän, vaikka elinikäiselle oppimiselle ei olekaan asetettu selkeästi ja täsmällisesti määriteltyjä tavoitteita. Toisaalta Elinikäisen oppimisen strategia-mietintö vuodelta 1997 sekä Koulutuksen ja tutkimuksen kehittämissuunnitelma vuosille 1999-2004 luovat varsin yhtenäisen tavoitekehyksen elinikäiselle oppimiselle, ja se on sopusoinnussa myös Euroopan unionin tavoitteiden kanssa.

Edellä mainitun tavoitekehyksen pohjalta elinikäiselle oppimiselle voidaan Suomessa asettaa seuraavat yleiset tavoitteet:

- kaikkien ikävaiheiden huomioonottaminen oppimisessa ja koulutuksessa,

- koulutusjärjestelmän ulkopuolella hankittujen tietojen ja taitojen tunnistamisjärjestelmien laajentaminen ja kehittäminen,

- joustavuuden ja valinnanmahdollisuuksien takaaminen koulutuksessa,

- ohjauksen ja neuvonnan parantaminen,

- työssä oppimisen ja oppimistaitojen kehittäminen,

- koulutuksen laadun parantaminen sekä

- koulutuksen tukijärjestelmien (esimerkiksi tietoteknikka ja rahoitus) kehittäminen.

Tässä katsauksessa pohdimme, miten elinikäisen oppimisen tavoitteet toteutuvat Suomessa aikuis- koulutuksen näkökulmasta. Tarkastelu perustuu Cedefop:lle laadittuun maaraporttiin (Nyyssölä \& Hämäläinen 2001a; ks. myös Nyyssölä \& Hämäläinen 2001b). Tämän lisäksi analysoimme elinikäisestä oppimisesta laadittuja kansainvälisiä raportteja.

\section{Rahoitus}

$\mathrm{R}$ iittävä resursointi on elinikäisen oppimisen perusedellytys. Aikuisten ammatillisen perus- ja lisäkoulutuksen rahoitusjärjestelyt ovat kehittyneet vähitellen 1980-luvulta alkaen. Aikuisten koulutuskustannusten rahoitus silloin, kun kysymys on nuorten koulutukseen rinnastettavasta tutkintoihin tähtäävästä peruskoulutuksesta, on opiskelijoille maksutonta ja siten yhtenäistä. Myös aikuisille suunnatun niin sanotun vapaan sivistystyön valtionrahoituksen perusteet ovat yhtenäiset.

Aikuisten ammatillisen lisä- ja täydennyskoulutuksen rahoitusperusteissa tilanne on monimuotoisempi. Samansisältöistä koulutusta voidaan rahoittaa oppilaitosmuodosta ja rahoituslähteestä riippuen kovin monin eri perustein. Toisistaan poikkeavat rahoitusperusteet merkitsevät, että hinnoittelun puolesta kilpailu voi olla vääristynyttä. Tällä ei tarkoiteta sitä, etteikö julkinen sektori voi rahoittaa myös aikuisten lisäja täydennyskoulutusta, vaan että julkisen sektorin toimijaa on tällöin tarkasteltava myös koulutuksen ostajana.

Lisäksi ei ole vielä kyetty laatimaan tavoitteita siitä, minkälaisilla osuuksilla yksityinen sektori (työnantajat ja yksilöt) osallistuu koulutuskustannuksiin. Tämän asian selvittäminen ja ratkaiseminen on kiireellinen tehtävä paitsi koulutuspoliittisen merkityksensä, myös sen vuoksi, että valtion rahoitus ammatilliseen lisä- ja täydennyskoulutukseen on supistunut huomattavasti viime vuosina.

Kaiken kaikkiaan Suomen koulutusjärjestelmän ja aikuiskoulutuksen rakenteellinen, institutionaalinen ja rahoituksellinen perusta on kuitenkin monipuolinen ja vahva ja se antaa hyvät edellytykset elinikäisen oppimiselle.

Rahoitusta voidaan tarkastella myös siten, kuinka paljon koulutusta on resurssoitu suhteessa 
bruttokansantuotteeseen. OECD:n tuoreessa $E d u$ cation at a Glance - raportissa (OECD 2001a) on vertailtu OECD-maiden koulutusmenojen osuutta bruttokansatuotteesta vuoden 1998 tilastojen pohjalta. Raportin mukaan koulutuksen kokonaismenot Suomessa olivat 5,7 \% bruttokansantuotteesta, mikä oli melko tarkkaan OECD maiden keskiarvo. Suurimmat koulutusmenot olivat Tanskassa (7,2 \%), Koreassa (7,0 \%) ja Norjassa (6,9 \%). Vuoden 1995 tilastoissa Suomen koulutusmenot olivat $6,3 \%$, joten laskua oli tapahtunut 0,6 pronsenttiyksikön verran. Vuosien 1995 ja 1998 välillä bruttokansatuote nousi Suomessa enemmän kuin koulutusmenot. Tilanne oli samanlainen suurimmassa osassa OECD maita. (OECD 2001a, 71. 74.)

\section{Elinikäisen oppimisen toteutumisen rakenteelliset ongelmat}

$V_{k}$ aikka elinikäiseen oppimiseen sisältyy jonkin verran koulutuspoliittista "liturgiaa", on se aidosti tullut osaksi koulutusjärjestelmää kaikilla tasoilla. Rahoitustilannetta voidaan myös pitää tyydyttävänä. Elinikäisen oppimisen toteutumisessa on kuitenkin erotettavissa neljä rakenteellista ongelmaa. Kaksi ensimmäistä näistä liittyy perusopetukseen ja kaksi jälkimmäistä aikuiskoulutukseen.

Ensinnäkin koulutuspalvelut eivät ole maantieteellisesti täysin tasa-arvoisesti saavutettavissa. Perusopetuksessa ongelmana on, että pieniä kouluja on lakkautettu runsaasti viime vuosina, mikä heikentää koulutustarjontaa syrjäseuduilla. Ammatillisessa koulutuksessa ongelmat liittyvät joustavien ja yksilöllisten kouluttautumismahdollisuuksien turvaamiseen.

Toiseksi koulutus- ja työelämä ovat edelleen varsin etäällä toisistaan Suomessa, vaikka työssä oppimista on lisätty tuntuvasti ammatillisessa koulutuksessa. Puolen vuoden laadukkaan työssäoppimisjakson järjestäminen kaikille ammatillisessa koulutuksessa oleville on mittava urakka, joka edellyttää yrityksiltä vahvaa sitoutumista. Työssä oppimisen pullonkaulaksi saattaa muodostua myös se, että opettajilla on usein varsin puutteelliset tiedot työelämästä ja lähiseudun elinkeinoelämästä.
Kolmanneksi non-formaalia ja informaalia oppimista ei hyödynnetä riittävästi. Suomen varsin joustava koululainsäädäntö antaa sinällään hyvät mahdollisuudet non-formaalin ja informaalin koulutuksen validoimiseen. Oppilaitostasolla tätä mahdollisuutta käytetään kuitenkin melko vähän. Keskeisin informaalin oppimisen validointimenetelmä on melko laajan suosion saanut näyttötutkintojärjestelmä. Näyttötutkinnoissa aikuiset voivat osoittaa tutkintotilaisuuksissa ammattitaitonsa siitä riippumatta, missä ja miten he ovat sen hankkineet. Opetushallituksen laatimissa tutkintojen perusteissa määritellään ammattitaito, joka tutkintotodistuksen saamiseksi on osoitettava.

Näyttötutkintojärjestelmä on selkeä askel kohti informaalin oppimisen laajempaa validointia. Näyttötutkintojen informaalisuutta himmentää kuitenkin se, että useimmiten näyttötutkintoa edeltää valmisteleva koulutusjakso oppilaitoksissa. Tutkijat ovatkin tuoneet esille huolensa, että näyttötutkinnot ovat vaarassa muuttua päättökokeeksi, jota määrittää pikemminkin edeltävä valmistava koulutus kuin työelämän vaatimukset.

Neljänneksi aikuiskoulutus ei saavuta kaikkia väestöryhmiä. Suurin työsarka elinikäisessä oppimisessa on nimittäin aikuisten kouluttamisessa. Ikäryhmien väliset koulutuserot ovat Suomessa kansainvälisesti suuret. Esimerkiksi 25-34 -vuotiaista $84 \%: 1 l a$ on vähintään toiseen asteen koulutus. Sen sijaan 55-64 -vuotiaista suomalaisista vain $41 \%: 11$ a on vastaavan tason koulutus. Ikäryhmien välisten osuuksien erotus on siis jopa 43 prosenttiyksikköä, mikä on OECD-maiden kolmanneksi suurin. (OECD 2000, 28.)

$\mathrm{N}$ uorista on siis huolehdittu hyvin, mutta vanhempien ikäryhmien koulutustason nostamisessa riittää vielä työtä. Ongelmaa kärjistää se, että aikuisopetukseen osallistuminen on edelleen kasautuvaa: siihen osallistuvat eniten ne, joilla on jo ennestään hyvä pohjakoulutus. Toisaalta on myös esitetty, että kaikkia ei voi saada väkisin osallistumaan koulutukseen. Vastuu elinikäisestä oppimisesta kuuluu myös yksilölle itselleen. 


\section{Elinikäinen oppiminen kansainvälisessä tarkastelussa}

OECD:n julkaisemassa Education Policy Analysis-raportissa (OECD 2001b) on ensimmäisen kerran tehty systemaattista inventaariota siitä, missä vaiheessa maat ovat ajatelleet elinikäisen oppimisen realisointia. Erityinen huomio kohdistettiin kahteen laajaan elinikäisen oppimisen tavoitteeseen: jatko- ja täydennyskoulutuksen kattavuuteen ja tuotoksiin sekä voimavarojen hallinnointiin ja suuntaamiseen. Tätä analyysia varten koottiin laajasti vertailevaa tietoa koulutukseen osallistumisesta, suoritetuista opinnoista, lukutaidosta ja rahoituksesta.

Yleinen havainto on se, että varsin vähälukuinen joukko maita on onnistunut kunnolla toteuttamaan elinikäistä oppimista käytännössä. Suurimmassa osassa OECD-maista elinikäinen oppiminen on vielä keskeneräinen agenda. Analyysin perusteella joukko jäsenmaita näyttää saavuttaneen tasapainon eri elinikäisen oppimisen sektorien kehittämisessä. Näitä maita ovat ennen kaikkea Pohjoismaat, missä myös koulutukseen käytetään eniten julkisia varoja suhteessa bruttokansantuotteeseen. Seuraavaksi parhaiten menestyneeseen ryhmään kuuluvat Kanada, Tšekin tasavalta, Saksa, Hollanti ja Uusi-Seelanti. OECD-maissa on myös havaittavissa rohkaisevia merkkejä siitä, että muodollisen koulutuksen tehokkuus on kasvamassa. Tämä vähentää lisärahoituksen tarvetta koulutuksen kasvun turvaamiseksi.

M yös Euroopan tasolla on analysoitu elinkäisen oppimisen konkreettista toteutumista. EU-jäsenmaissa sijaitsevat kansalliset Eurydice -yksiköt ovat keränneet projektikohtaisia tietoja ja toimittaneet ne verkoston pääyksikköön Brysseliin yhteenkokoamista ja toimitustyötä varten. Lopputulos eli raportti National actions to implement Lifelong Learning in Europe (Eurydice 2001b) on melko kattava, mutta sirpaleinen luettelo käytännön elinikäisen oppimisen toimenpiteistä kansallisella tasolla. Maiden erilaisista tilanteista johtuen johtopäätösten teko näyttää raportin perusteella olleen erittäin vaikeaa ja tulosten lopullinen analyysi on vaatimatonta. Raportin pääasiallinen funktio onkin lä- hinnä esitellä käytännön toimenpiteitä eri maissa. Julkaisu sinänsä tukee Euroopan komission lokakuun 2000 elinikäisen oppimisen muistiota, joka puolestaan on jatkanut maaliskuun 2000 Lissabonin Eurooppa-neuvoston suosituksia.

Kootun materiaalin perusteella Eurydice pystyy kuitenkin tunnistamaan trendejä, jotka ovat vallitsevia Euroopan tasolla. Kaikkialla korostetaan uusien työelämässä tarvittavien taitojen, kuten tietotekniikan ja vieraiden kielten oppimista, mutta tarvetta on myös kyvylle selviytyä uudenlaisissa oppimisympäristöissä esimerkiksi vieraista kulttuureista tulevien työntekijöiden kanssa. Koulutuksen rahoituksen osalta on nähtävissä, että siihen varattujen rahojen kokonaismäärää ei olla kasvattamassa juuri missään, mutta monissa maissa voimassaolevaa rahoitusta kohdennetaan uudelleen elinikäisen oppimisen tarpeiden mukaisesti. Tämä näkyy esimerkiksi panostuksena esiopetukseen, trendi, joka on Suomessakin ollut hyvin esillä.

Myös oppimisympäristöt ovat muuttumassa alati joustavammiksi ympäri Eurooppaa, erityisesti tietotekniikan kehittymisen myötä. Tiedonsaanti tarjottavista kursseista ja koulutusohjelmista on nykyisin helpompaa ja mahdollistaa yksilöittäin räätälöidyn opiskeluohjelman. Tietotekniikka liittyy läheisesti myös opettajankoulutuksen kehittämiseen. Paitsi, että sen tehokkaampi käyttö opetuksessa ja opettaminen oppiaineena on asettanut uusia vaatimuksia opettajien pätevyysvaatimuksille, atk mahdollistaa Eurydice -raportin mukaan myös opettajien keskinäisen kommunikaation (esimerkiksi keskusteluryhmien välityksellä) parantaen ja tukien näin heidän työmotivaatiotaan. Raportti mainitsee myös Suomen aseman julkisten kirjastopalvelujen kehittäjänä. Sen mukaan tietokoneiden käyttövalmius kirjastoissa edesauttaa aikuisväestön tutustumista tietotekniikan mahdollisuuksiin ja heidän tietoteknisten taitojensa kehittymistä.

Elinikäisen oppimisen konseptiin kuuluu olennaisesti non-formaali oppiminen ja sen kasvavassa määrin tunnustettu asema osana koulutustarjontaa. Raportti ei analysoi non-formaalia oppimista sinänsä, mutta listaa siihen kuuluvia yleiseurooppalaisia projekteja, joissa pääpaino on itse oppimisprosessin korostamisessa, ei niinkään virallisen tutkintotodistuksen saamisessa. Tällai- 
sia aloitteita ovat esimerkiksi tietokoneajokortti (European Computer Driving Licence), tutkintojen tunnustamisjärjestelmä (European Credit Transfer System) sekä EUROPASS -todistus, jonka avulla todennetaan toisessa EU- tai ETA -maassa suoritettu ammattiin valmentava koulutusjakso. Eurooppalaisen koulutusyhteistyön lisääntyessä kasvaa tarve myös informaatio- ja opastuspalveluille, joita on pyritty toteuttamaan esimerkiksi Euroopan komission koordinoiman Eures -palvelun avulla. Eures välittää tietoa työmahdollisuuksista muissa Euroopan maissa potentiaalisille työnhakijoille. Lisäksi erityisesti nuoria työnhakijoita varten on perustettu oma Eurodesk palvelu, joka Suomessa sijaitsee Kansainvälisen henkilövaihdon keskuksessa CIMO:ssa.

Ceini edefop on teettänyt maakohtaisia selvityksiä elinikäisen oppimisen toteuttamiseksi. Aiemmin tässä artikkelissa mainitun Suomea koskevan raportin lisäksi tätä kirjoitettaessa oli saatavilla Ruotsin selvitys. Tukholman yliopiston kansainvälisen koulutuksen instituutin tutkijoiden Ann Kristin Boströmin, Emmanuel Boudardin ja Petroula Siminoun (2001) laatima kuvaus on yleinen, mutta kattava kuvaus elinikäisen oppimisen toteutumisesta Ruotsin ammatillisessa koulutuksessa. Se pyrkii kuvaamaan muutoksia erityisesti vuoden 1991 paikallishallintolain tuomien uudistusten valossa. Tuo lakihan antoi kunnille ja kuntayhtymille mahdollisuuden soveltaa haluamaansa hallintomallia koulutukseen, tosin tiettyjen perussäännösten pohjalta.

Raportin perusteella käy selvästi ilmi, että ruotsalainen infrastruktuuri sopii hyvin elinikäisen oppimisen tarpeisiin: sekä formaalin että nonformaalin oppimisen vaihtoehdot mahdollistavat kouluttautumisen työ- ja vapaa-aikana. Erityisen tärkeänä raportin toimittajat pitävät mahdollisuutta opintovapaaseen, joka Suomessakin on jo varsin laajassa käytössä. Ruotsissa on niin ikään investoitu voimakkaasti ammatillisen koulutuksen kehittämiseen sinänsä. Opetus- ja tiedeministeriön sekä teollisuus-, työ- ja viestintäministeriön kesken jaettu ammatillisen koulutuksen vetovastuu näyttää ottavan hyvin huomioon koulutussuunnittelun ja työelämän tarpeet. Tämän työnjaon seurauksena lukion ja ammatillisen koulutuksen välinen ja aiemmin itsestään selvä tiukka rajanveto on poistunut kokonaan.

Raportin kirjoittajien mielestä Ruotsi on selvästi matkalla kohti aitoa elinikäisen oppimisen yhteiskuntaa, jossa valtio investoi vuosittain yhä enemmän rahaa ja voimavaroja koulutusjärjestelmään. Esimerkiksi vuoteen 2002 mennessä tulisi kehittää huomattavasti opettajien tietotaitoja ja saada aikaan lakiin perustuva aikuiskoulutusjärjestelmä. Boström, Boudard ja Siminou toteavat kuitenkin, ettei tämäkään investointitaso vielä riitä, jos vertailukohtana käytetään jonkinlaista ihanteellista elinikäisen oppimisen järjestelmää, jossa kaikki kansalaiset käyttäisivät aktiivisesti aikaansa itsensä kouluttamiseen koko elämänkaarensa ajan.

\section{Lopuksi}

— linikäisestä oppimisesta on tullut sekä kansallisesta että kansainvälisestä näkökulmasta tarkasteltuna keskeinen eri maiden koulutuspolitiikkaa ohjaava ajattelutapa. Jokaisella maalla on oma toteuttamistapansa ja painopistealueensa. Tästä huolimatta ainakin seuraavat kolme elinikäisen oppimisen teemaa näyttävät nousevan keskeisiksi eurooppalaisella tasolla: oppimisedellytysten parantaminen, tietotekniikan hyödyntäminen sekä non-formaalin ja informaalin opitun tunnustaminen.

Myös Suomi on panostanut näihin koulutuksen kehittämisen osa-alueisiin. Suomi on muutoinkin muiden Pohjoismaiden rinnalla kehityksen kärjessä elinikäisen oppimisen käytännön soveltamisessa. Suomessa elinikäinen oppiminen on ehkä yllättävänkin sujuvasti löytänyt tiensä esimerkiksi opetussuunnitelmien perusteisiin, jotka käytännön tasolla ohjaavat opetuksen sisältöjä oppilaitoksissa.

Toisaalta elinikäisen oppimisen toteuttamiseen sisältyy rakenteellisia ongelmia, joista osa (esimerkiksi koulutuksen alueellinen epätasaarvo) on pitkäaikaisia koulutuspoliittisia perusongelmia. Tässä kohden herääkin kysymys, onko elinikäinen oppiminen todellakin koulutuspolitiikkaa ohjaava periaate vai ovatko perinteiset koulutuspoliittiset tavoitteet vain käännetty elinikäisen oppimisen formaattiin sopivaksi. Epäi- 
lemättä kumpaakin toimintatapaa esiintyy, mutta kokonaisuudessaan elinikäinen oppiminen on Suomessa enemmän uuden omaksumista kuin vanhan kierrättämistä.

Elinikäinen oppiminen on saanut osakseen myös runsaasti kritiikkiä. Useat tutkijat ovat kyseenalaistaneet elinikäisen oppimisen yhteiskunnallisena projektina. Ongelmaksi on nähty sen pakottava luonne. Monille elinikäinen oppiminen herättää ikävät muistot omilta kouluajoilta, jolloin käsite muuttuu ihmisten mielissä herkästi elinkautiseksi oppimiseksi. Tämä ei ainakaan kannusta kansalaisia kouluttamaan itseään. Elinikäinen oppiminen voidaan nähdä eräänlaisena koulun jatko-osana, joka ulottaa perinteiset koulun tehtävät - valikoinnin, integroinnin, sosiaalistamisen ja varastoinnin - säätelemään myös aikuisten elämää. Tutkijoiden piirissä keskustellaan myös siitä, vaatiiko työelämä todellakin kaikilta jatkuvaa kouluttautumista.

Vallitsevaa perusnäkemystä elinikäisen oppimisen tarpeellisuudesta on kuitenkin hankala täysin kyseenalaistaa, saati että sille voitaisiin esittää realistisesti toteuttavia vaihtoehtoja. Sen sijaan keskustelua pitäisi käydä enemmän elinikäisen oppimisen strategisista tavoitteista ja painopistealueista sekä siitä, miten asetetut tavoitteet voidaan saavuttaa. Koulutuspoliittisella tasolla nämä asiat ovat edelleen varsin epämääräisesti hahmotettavissa. Perusongelmana on, että Suomelta puuttuu selkeä strategia elinikäisen oppi- misen toteuttamisesta. Elinikäinen oppiminen vaatii nykyistä täsmällisemmät tavoitteenasettelut ja tavoitteiden toteutumisen arvioinnin.

\section{Lähteet}

BOSTRÖMIN, A.K, Boudardin, E. \& Siminoun, P (2001). Lifelong Education in Sweden. Cedefop, Thessaloniki.

EU (2000). Draft Memorandum on Lifelong Learning. European Commission.

EURYDICE (2001a). Avarage/esimate number of computers per schools and avarage/estimate number of pupils per computer. Primary and secondary education. First dratft/Preliminary document.

EURYDICE (2001b). National actions to implement Lifelong Learning in Europe. Eurydice Survey 3. Brussels.

HAUTAMÄKI, J. et al. (1999). Oppimaan oppiminen ala-asteilla. Oppimistulosten arviointi 3/1999. Helsinki: Opetushallitus.

KALLI, P. (2000). Näkökulmia verkkopedegogiikkaan. Aikuiskasvatus (20), 2, 135-138.

KIVINIEMI, K. (2000). Johdatus verkkopedagogiikkaan. Keski-Pohjanmaan Ammattikorkeakoulu, Kokkola.

KM (2001:20). Oppivelvollisuusiän alentamisen vaikutuksista. Komiteanmietintö. Helsinki.

NYYSSÖLÄ \& Hämäläinen (2001a) (ed.) Lifelong learning in Finland. Cedefop, Thessaloniki.

NYYSSÖLÄ \& Hämäläinen (2001b) (toim.) Elinikäinen oppiminen Suomessa. Opetushallitus, Helsinki.

OECD (2000). Education at a Glance. Paris: OECD.

OECD (2001a). Education at a Glance. Paris: OECD

OECD (2001b): Education Policy Analysis. Education and Skills. OECD, Paris.

OPH (2000). Opetushallituksen vuosittain keräämät tilastot peruskoulujen, lukioiden ja ammatillisista oppilaitosten tietotekniikkaresursseista. Vuoden 1999 tilanne. Julkaisematon moniste. 